\title{
SVĀRSTMIGRĀCIJA RīGAS AGLOMERĀCIJAS IEKŠĒJĀ ZONĀ. BABĪTES NOVADA PIEMĒRS
}

\section{Toms Skadiṇ̌}

LU G̦ZZF, e-pasts: tomsskadins@inbox.Iv

\begin{abstract}
Anotācija. Svārtsmigrācija kḷ̂̄st par arvien izteiktāku parādību urbanizācijas un suburbanizācijas dēḷ. Šis process ir izplatīts visā pasaulē. Latvijas gadījumā svārstmigrācija ir process, kas ir īpaši raksturīgs Rīgas aglomerācijai (lai gan svārstmigrācija pastāv arī citās valsts daḷās, taču tur tā nav tik izteikta), it īpaši novadiem un pagastiem, kas atrodas aglomerācijas iekšējā zonā. Lai arī svārstmigrācija šajās teritorijās ir raksturīgāka, tomēr arī tajās pastāv atšķirības (arī novada līmenī), kuras iepriekš ir maz pētītas. Šajā rakstā tām tiek pievērsta padzilịnātāka uzmanība.
\end{abstract}

Atslēgas vārdi: svārstmigrācija, aglomerācija, Babīte, Piṇkịi, salīdzināšana.

Svārstmigrācija pieder pie geogrāfiskās mobilitātes, kas šobrīd ir viens no nozīmīgākajiem pētījumu virzieniem ǵeogrāfijā. Iedzīvotāju pārvietošanās mūsdienās kḷust arvien svarīgāka. Svārstmigrāciju veicina tādi faktori, kā piemēram, suburbanizācija un ekonomiskie rādīiāji. Austrumeiropā un Centrāleiropā (līdz ar to arī Latvijā) palielinās piepilsētu iedzīvotāju skaits (Brown, Schafft 2002; Leetmaa et al. 2009; Tammaru and Kontuly 2011). Iedzīvotāju skaita pieauguma rezultātā palielinās arī svārstmigrantu skaits (Ahas et al. 2010; Novák, Sýkora 2007; Tammaru 2005). Gan Latvijā, gan citās postsociālisma valstīs ir veikti vairāki pētījumi par svārstmigrāciju (Ahas et al. 2010; Krišjāne, Bērziņš 2009; Krišjāne et. al 2012), tomēr vairāk pētijumu ir par mobilitāti, kur svārstmigrācija ir tikai viens no pētijjumu objektiem. Mazāka uzmanība tiek pievērsta arī aglomerācijai un tās sastāvdaļām (zonām). Būtu svarīgi analizēt arī svārstmigrācijas īpatnību atškirīības, piemēram, viena novada līmenī.

Pêtījuma mêrķis ir izpētīt un novērtēt svārstmigrācijas procesu Rīgas aglomerācijas iekšējā zonā, izmantojot Babītes novada piemēru. Lai arī Babītes novads atrodas iekšējā zonā, tomēr tā nav homogēna teritorija. Novada austrumu dą̧a (kur atrodas Babītes un Piņ̧̧̧u ciemi) atrodas tuvāk Rīgai (un Jūrmalai) un tur ir labāks transporta tīkls un nodrošinājums. Bet arī starp šīm apdzīvotajām vietām ir atṣ̌̌irības (gan iedzīvotāju skaita, gan teritorijas funkciju zin̄ā). Babītes novads robežojas ar Rīgas un Jūrmalas pilsētam. Līdz ar to ir svarīgi novērtēt novada (šajā gadījumā Babītes un Piņķu ciemu) saikni ar abām pilsētām (it īpaši, cik liela nozīme ir Jūrmalai).

\section{Materiāli un metodes}

Darba izstrādei tiek izmantoti šādi dati: zinātniskie raksti un pētījumi par svārstmigrāciju (arī mobilitāti) un aglomerāciju, anketēšanas rezultāti (un LU ĢZZF CG̣ katedras materiāli, dati par Babītes un Piṇku ciemiem, kopskaitā 155 anketas par katru apdzīvoto vietu). Darba metodes ietver literatūras analīzi, primāro un sekundāro datu iegūšanu un analīzi, kā arī rezultātu apkopošanu un skaidrošanu. Datu analīzei tika izmantota datorprogramma Microsoft Excel. 


\section{Rezultāti}

No visiem respondentiem Babītes ciemā, kuri strādā vai mācās, par svārstmigrantiem var uzskatît $77 \%$ jeb 120 aptaujātos. Rīgā strādā vai mācās 110 respondenti (71\%), uz citām pašvaldībām dodas 10 (6\%), lielākā daḷa (8) dodas uz Jūrmalu, 2 - uz Ķekavas novadu. Vietējā pašvaldībā strādā/mācās 23\% jeb 35 respondenti. Savukārt Piņ̣̂u gadījumā par svārstmigrantiem var uzskatīt $65 \%$ jeb 101 aptaujāto, uz citām pašvaldībām dodas 8 (5\%), 6 dodas uz Jūrmalu, 2 uz Olaini. Rīgā strādā vai mācās 93 respondenti (60\%). Vietējā pašvaldībā strādā/mācās $35 \%$ jeb 54 respondenti. Ja saistībā ar citās pašvaldībās strādājošo (mācošos) skaita atšķirības tikpat kā nav, tad abos pārējos rādītājos atšķirības pastāv. Babītē ir par 11\% (19) lielāks svārstmigrantu skaits nekā Piņ̧̧̧os, savukārt Piņ̧̧os to respondentu skaits, kuri mācās/strādā vietējā pašvaldība ir par 12\% (19) vairāk nekā Babītē.

Babītes iedzīvotājiem, salīdzinot ar daudzu citu Pierīgas teritoriju iedzīvotājiem, ir visai plašas transporta izvēles iespējas. Visai līdzīgi ir sadalījušies trīs transporta veidi autobusu ceḷam uz darbu vai mācību vietu izvēlas 38\% (45 respondenti), personīgās automašīnas 33\% (40 respondenti) un vilcienu izmanto 28\% (33 respondenti). Mikroautobusu izmanto vien 2\% (2 respondenti). Kopumā sabiedriskā transporta īpatsvars ir uz pusi lielāks (80 pret 40). Piņķos tik plašas izvēles iespējas nav (lai gan autobusu maršrutu skaits ir lielāks). Respondenti par savu pārvietošanās veidu norādīja vai nu autobusu, vai arī automašīnu. Ar autobusu pārvietojas 58\% (59 respondenti), savukārt personīgās automašīnas izmanto $42 \%$ (42). Lai arī degvielas cenām ir tendence samazināties, sabiedriskais trasnports ir izdevīgāks, pat ja jāveic neliels attālums. Arī labais sabiedriskā transporta nodrošinājums (Pasažieru vilciens 2016; Rīgas satiksme 2016) ietekmē transporta izvēli. Savukārt mazo mikroautobusu izmantošanas rādītāji ir mazi, jo tie reti kursē un maršruts ir neizdevīgs.

1. tabula. Svārstmigrantu darba vietas un to apmeklējuma sadalījums Babītes un

Pinḳu ciemos

\begin{tabular}{|l|c|c|c|c|c|}
\hline Darba vieta & $\begin{array}{c}\text { Uz visu } \\
\text { darba } \\
\text { nedēḷu }\end{array}$ & $\begin{array}{c}\text { Ik } \\
\text { darbdienu } \\
\text { un biežāk }\end{array}$ & $\begin{array}{c}\text { 3-4 reizes } \\
\text { nedēḷā }\end{array}$ & $\begin{array}{c}\text { 1-2 reizes } \\
\text { nedēḷā }\end{array}$ & $\begin{array}{c}\text { Kopējais } \\
\text { skaits }\end{array}$ \\
\hline Rīga & 9 & 83 & 14 & 4 & 110 \\
\hline $\begin{array}{l}\text { Cita } \\
\text { pašvaldība }\end{array}$ & 0 & 9 & 1 & 0 & 10 \\
\hline Rīga & 8 & 72 & 10 & 3 & 93 \\
\hline $\begin{array}{l}\text { Cita } \\
\text { pašvaldība }\end{array}$ & 0 & 7 & 1 & 0 & 8 \\
\hline
\end{tabular}

Ja salīdzina svārstmigrantu ceḷā pavadīto laiku tiem, kuri izmanto personīgās automašīnas un tiem, kuri izmanto kādu sabiedrisko transportu, tad Babītes gadījumā ir redzams, ka atškirība nav liela - tie, kuri izmanto automašīnas, ceḷā pavada 32,5 minūtes, bet tie, kuri izmanto sabiedrisko transportu, 33,4 minūtes. Piņ̧̧u gadījumā tās ir attiecīgi 32,8 un 33,7 minūtes. Gan Piṇķu, gan Babītes gadījumā atšķirības nav statistiski būtiskas. 
Lai arī šobrīd par svārstmigrantiem uzskata tos, kuri uz citu pašvaldību brauc strādāt/mācīties vienu līdz divas reizes nedẹ̦ā, tomēr šādu cilvēku īpatsvars ir mazs. Vairākums ir klasiskie svārstmigranti, lielākā daḷa uz savu darbu vai mācību vietu dodas ik darbdienu un biežāk (1. tabula). Lai arī darba specifika mainās, tomēr joprojām izteikta ir piecu dienu darba nedēḷa.

\section{Secinājumi}

- Lai arī Babītes novads robežojas ar Rīgu un Jūrmalu, tomēr svārstmigrācijas kontekstā daudz ciešāka saikne ir ar Rīgu. Iedzīvotāji uz Jūrmalu biežāk brauc iepirkšanās vai dažādu izklaides pasākumu dēḷ.

- Svārstmigrācija gan no Babītes, gan Piņ̧̧iem uz Rīgu ir izteikta (attiecīgi 110 no 120 un 93 no 120 tur strādā/mācās).

- Joprojām lielākā daḷa svārstmigrantu pieder pie klasiskajiem svārstmigrantiem (strādā/mācās citā pašvaldībā vismaz 3-4 dienas nedẹ̄̂ā).

- N̦emot to, ka nav statistiski būtiskas atšķirības starp tiem, kuri izmanto personīgas automašīnas un tiem, kuri izmanto kādu sabiedrisko transportu, galvenais iemesls, kāpēc sabiedrisko transportu izmanto uz pusi vairāk respondentu, ir izmaksas.

- Lielo Rīgas īpastvaru var skaidrot ar to, ka galvaspilsētā ir plašākas darba un izglītības iespējas, kā arī virzienā uz Rīgu ir labāks transporta nodrošinājums.

- Salīdzinot svārstmigrantu īpašības Piņķos un Babīte lielākās atšķrības ir svārstmigrantu skaita ziṇā, kas varētu būt skaidrojams ar to, ka Piṇķos ir plašākas darba iespējas. Saistībā ar pārējiem rādītājiem atšķ̧irības nav būtiskas.

\section{Atsauces}

Ahas, R., Aasa, A., Silm, S., Tiru, M. (2010). Daily rhythms of suburban commuters' movements in the Tallinn metropolitan area: case study with mobile positioning data. Transportation Research. Part C, 18, 45-54.

AS Pasažieru vilciens. Vilcienu maršrutu kustības saraksti: http://www.pv.lv/lv/vilcienu_saraksts/?stop_from=213\&stop_to=1 (21.02.2016.)

Brown, D., Schafft K.A. (2002). Population deconcentration in Hungary during the postsocialist transition. Journal of Rural Studies, 18, 233-244.

Krišjāne, Z., Bērziņš, M. (2009). Commuting and the deconcentration of the post-socialist urban population: The case of the Riga agglomeration. Folia Geographica XIV, 56-74.

Krišjāne, Z., Bērziņš, M., Ivlevs, A., Bauls, A. (2012). Who are the typical commuters in the post-socialist metropolis? The case of Riga, Latvia. Cities, 29(5),. 334-340.

Leetmaa, K., Tammaru, T., Anniste, K. (2009). From priority-led to market-led suburbanisation in a post-communist metropolis. Tijdschrift voor Economische en Sociale Geografie, 100 (4), 436-453.

Rīgas satiksme. Maršruti un kustību saraksti. Pieejams http://saraksti.rigassatiksme.lv/index.html\#riga (21.02.2016)

Tammaru, T., Kontuly, T. (2011). Selectivity and destinations of ethnic minorities leaving the main gateway cities of Estonia. Population, Space and Place, 17 (5), 674-688. 


\section{Summary}

This article focuses on characteristics of commuters that live in two villages in Babīte County - Babīte and Pinkịi. A total of 310 people (comprised of working people and students) were part of a survey to analyse general characteristics of commuters and identify possible differences between the two groups. Even though Babīte County borders both the cities of Rīga and Jūrmala, the amount of commuters to Jūrmala is insignificant. The majority of commuters work or study in Rīga, and are classified as classical commuters. More people use public transportation than automobiles as their primary means of transportation due to lower expenses. The city of Rìga attracts commuters with better professional and educational opportunities. The major difference between the inhabitants of the two villages is the fact that there are $11 \%$ fewer commuters in Piṇķi than in Babīte. This could be explained by better job prospects in Piṇkii. 